\title{
A Review of Low-Level Laser Therapy for Spinal Cord Injury: Challenges And Safety
}

\author{
Saeed Vafaei-Nezhad ${ }^{1}$, Mahnaz Pour Hassan ${ }^{1}$, Mohsen Noroozian², Abbas Aliaghaei², Atefeh Shirazi Tehrani ${ }^{3,2}$, \\ Hojjat Allah Abbaszadeh ${ }^{{ }^{*}}$, Shahrokh Khoshsirat ${ }^{{ }^{*}}$
}

${ }^{1}$ Laser Application in Medical Sciences Research Center, Shahid Beheshti University of Medical Sciences, Tehran, Iran ${ }^{2}$ Department of Biology and Anatomical Sciences, School of Medicine, Shahid Beheshti University of Medical Sciences, Tehran, Iran

${ }^{3}$ Faculty of Paramedical Science, Proteomics Research Center, Shahid Beheshti University of Medical Sciences, Tehran, Iran

\author{
*Correspondence to \\ Hojjat-Allah Abbaszadeh, Laser \\ Application in Medical Sciences \\ Research Center and Anatomical \\ Sciences, School of Medicine, \\ Shahid Beheshti University of \\ Medical Sciences, Tehran, Iran. \\ P.O.Box: 19395-4719. \\ Tel:+98-21-23872555; \\ Fax:+98-21-22439976 \\ Email: Dr.abbaszadeh@sbmu.ac.ir; \\ Shahrokh Khoshsirat,Hearing \\ Disorders Research Center \\ Loghman Hakim Center, Shahid \\ Beheshti University of Medical \\ Sciences, Tehran, Iran
}

Published online October 3, 2020

\begin{abstract}
Introduction: Damage to the spinal cord is a central nervous system disorder that results in direct damage to neural cells (axons, cell bodies) and glia, followed by autonomic, motor and sensory impairments. Inflammatory response after this injury can contribute to secondary tissue damage that leads to further behavioral and functional disorders. Inflammation is a complex process, which occurs after an injury. If this progressive process is not well controlled can lead to additional damage to the spinal cord which is preventing neural improvement and regeneration and, which ultimately will not provide good clinical consequences. Inflammation in the injured spinal cord is a physiological response that causes the death of glial and neuronal cells. The reduction of the initial inflammatory process after damage to the spinal cord is one of the important therapeutic strategies. It has been proposed that low-level laser (LLL) therapy, as a noninvasive manner, can modulate inflammatory processes, which leads to a significant improvement in neurological symptoms after spinal cord injury (SCI).

Methods: A comprehensive review was performed on $\mathrm{SCl}$, the etiologies, and treatment methods using the keywords spinal cord injury, low-level laser, and inflammation in valid medical databases such as Google Scholar, PubMed, and Elsevier (76 articles). Among the collected papers, articles that were most relevant to the purposes of the study were selected and studied.

Results: LLL therapy was able to reduce inflammation and also attenuate neuronal damage after spinal cord damage.

Conclusion: The present study illustrates that LLL therapy has positive effects on improving functional recovery and regulating the inflammatory function in the $\mathrm{SCl}$.

Keywords: Spinal cord injury (SCl); Inflammation; Low-level laser therapy.
\end{abstract}

\section{Introduction}

Spinal cord injury (SCI) is the main disorder in the central nervous system that specified by sensory, motor, and autonomic function impairments. SCI is followed by interruption of neuronal signaling along the spinal pathways. Restrictions on SCI have negative economic, social, and individual effects on patients with SCI. ${ }^{1-5}$ The incidence of SCI which is more common in men than in women has approximate ranges from 3.6 to 195 cases per million each year. ${ }^{6,7}$

In previous studies, according to the mechanism of injury, spinal cord injuries have been classified into two traumatic and non-traumatic types. ${ }^{8,9}$ The traumatic type of SCI is caused by such events as falling, vehicle accidents, sport, and violence. These events may cause a fracture in the spinal column, which is an important factor in exerting physical pressure on the spinal cord tissue, leading to loss of neurological function below the level of injury. ${ }^{8,10}$ In the non-traumatic type of SCI, factors like the infection, degenerative disk disease, and the tumor can cause SCI. As a result, SCI can cause extensive cellular damage, necrosis, and apoptosis, in neuronal and glial cells. ${ }^{11,12}$ In addition to the division mentioned above, according to the pathophysiology of injury, researchers have divided the spinal cord injuries into primary and secondary injuries. ${ }^{13-16}$ Primary injury begins immediately after injury which often results from mechanical impactions on the spinal cord, such as contusion, compression, stretching, penetration, and laceration. ${ }^{1,16}$ This phase is well characterized by acute

Please cite this article as follows: Vafaei-Nezhad S, Pour Hassan M, Noroozian M, Aliaghaei A, Shirazi Tehrani A, Abbaszadeh HA, et al. A Review of Low-Level Laser Therapy for Spinal Cord Injury: Challenges and Safety. J Lasers Med Sci. 2020;11(4):363-368. doi:10.34172/ jlms.2020.59 
hemorrhage and ischemia in the spinal cord tissue. The secondary injury which is characterized by neuronal and glial cell death starts after primary injury and can last up to weeks. ${ }^{17-19}$ In addition, the injury site can be extended to non-injured tissue. In the center of the injury site, fluidfilled cysts and glial scars are often formed. However, the precise mechanism of secondary injury is incompletely understood. ${ }^{20}$ Previous studies suggested that secondary damage can be divided into three phases: the acute phase, the subacute phase, and the chronic phase, each with different various pathophysiological processes. ${ }^{16,21,22}$ Secondary injury is a complex and progressive process that includes inflammation, the death of neurons and glial cells, ischemia, excitotoxicity and electrolyte imbalances, free radical's production, lipid peroxidation, and demyelination of surrounding neurons. . $^{11,20,23-26}$ The secondary phase makes the principal cause for the morbidity occurring in patients with damage to the spinal cord. ${ }^{19}$

\section{Inflammation in Spinal Cord Injury}

Stress and inflammation are major causes of damage to the central nervous system. ${ }^{27}$ The results of earlier studies have shown that the damage does not affect the whole structure of the spinal cord. In the animal model, Contusion and compression types of SCI are common in research. ${ }^{3,15}$ The primary injury in contusion and compression models can cause tension and rupture in the spinal cord vessels. ${ }^{1}$ Traumatic SCI initiates an inflammatory response that is one of the main causes of symptoms of SCI. ${ }^{19}$ Immediately after an injury to the blood-brain barrier, the inflammatory response is initiated by resident immune cells (astrocytes and microglia), peripheral immune cells (neutrophils, macrophages, and monocytes) and also the release of their chemical mediators. ${ }^{3,27,28} 8-24$ hours after the lesion, peripheral immune cells can be observed inside the spinal cord tissue. Activated microglia can be observed on the first day after the injury, reaching their highest levels from day 3 to day 7 . Neutrophils are the first leukocytes present in the lesion site from the first 3 to 12 hours after the lesion. ${ }^{29,30}$ Subsequently, 3-4 days after SCI, monocytes and macrophages infiltrate into the lesion site. ${ }^{3}$ It is well documented that, in an inflammatory response, the immune cells are one of the most important causes of neural cell degeneration. ${ }^{15,19}$ This reaction starts within hours after damage to spinal cord tissue and achieves peak values within a few days and it may continue for several years. ${ }^{15}$

The expression of TNF- $\alpha$ and IL- $1 \beta$ was observed by astrocytes and microglia 5-15 min. after injury. ${ }^{12,27}$ The peak of TNF- $\alpha$ and IL- $1 \beta$ expression are at 1 hour and 12 hours after injury, respectively. ${ }^{12}$ An in vitro study has shown that TNF- $\alpha$ and IL- $1 \beta$ can cause oligodendrocyte death and also inhibit glutamate transporters in astrocytes. ${ }^{31}$ In the secondary phase, TNF- $\alpha$ release from astrocytes can stimulate the additional release of this cytokine. It can also cause the accumulation of calcium in the neuronal cells. ${ }^{12,32}$ The principal effects of TNF- $\alpha$ on the SCI have not been clearly established. However, the researchers have suggested that in the primary phase of CNS damage, it can cause edema and immune cell migration, neuronal cell death, and also some neuroprotective effects. ${ }^{20}$

The inflammatory reactions expand within hours after damage to the spinal cord, achieving peak values within a few days. Likewise, the infiltration of peripheral immune cells is followed by macrophages and monocytes. ${ }^{8,15,33}$ TNF- $\alpha$ levels in the spinal cord elevate one hour after trauma. However, it is thought that it may lead to edema and immune cell migration, cell death, and some neuroprotective effects in the primary phase of SCI. ${ }^{20}$

Different approaches have been proposed to treat SCI in animal studies, such as the reduction of inflammation, the infusion of neurotrophic factors, the reduction of endogenous growth suppressors, and the transplantation of growth-promoting cells. ${ }^{34,35}$ In both developed and developing countries, the reduction of neurological impairments after SCI is the main problem facing the healthcare sector. ${ }^{6}$ Nowadays despite the use of various therapies such as drug therapy, gene therapy, hypothermia, tissue engineering, and transplantation of stem cells in patients with damage to the spinal cord, none of the above methods has completely eliminated the complications of this injury. ${ }^{11,36-41}$ It is well documented that reducing and controlling inflammation in SCI can reduce the complications in SCI models. ${ }^{33,42}$

\section{Low-Level Laser in SCI}

The results of some preliminary studies have clearly shown that the application of low-level laser (LLL) may have useful effects on central nervous system damage. ${ }^{43,44}$ Recently, the use of laser therapy, as a noninvasive procedure, has been considered one of the new therapeutic strategies for the treatment of wounds and burns, pain, osteoporosis, and periodontal diseases. ${ }^{36,43,45-50}$ Previous studies have suggested that lasers can affect the level of inflammatory factors such as TNF- $\alpha$ and IL- $1 \beta{ }^{51,52}$ They are also useful for neurological and neurodegenerative disorders such as traumatic brain injury, stroke, and damage to the spinal cord. ${ }^{44,53-56}$ In previous studies, lasers were divided into high and low power. High-power lasers have immediate effects and are most commonly used in surgical operations. Unlike high-power lasers, low-power lasers had no rapid tissue effects..$^{57}$ Moreover, the results from animal CNS injury studies have indicated that LLL may have helpful effects on the treatment of inflammatory conditions after CNS injury..$^{58-60}$ Experimental investigations in animals indicate that the use of LLL can decrease the post-traumatic inflammatory reactions and prevent the effects of reactive oxygen species (ROS) release and NF- $\kappa$ B activation. ${ }^{42,61,62}$ It is well documented that LLL can attenuate inflammation response and TNF- $\alpha$ 
level in Broncho alveolar lavage fluid animal models. ${ }^{51}$

The use of LLL can have an effect on cell performance by affecting the enzymes, organelles, and cell membranes. It is well documented that LLL can change physiological reactions by activating transcription factors, enhancing mitochondrial respiration, decreasing main inflammatory factors, increasing angiogenesis and neurogenesis to increase wound healing, repairing tissues, and decreasing inflammation. ${ }^{63,64}$ Evidence has also suggested that photobiomodulation is useful in reducing neuropathic pain and programmed cell death. ${ }^{65}$ Furthermore, some investigations have demonstrated that transcranial infrared laser therapy used in 6 and 24 hours after an ischemic stroke in animal models leads to significant recovery of neurological defects. ${ }^{56,66,67}$ Animal studies have shown that laser therapy prevents the aggregation of macrophages at the site of neuronal tissue injury and modulates the inflammation process, which promotes improvement in neuronal tissue repair and decreases injury complications by reducing the secretion of PEG2 and LTB4. ${ }^{68,69}$

A study by Gonçalves et al demonstrates that LLL therapy after SCI can decrease the inflammation reactions in the spinal cord by regulating the migration of immune cells in the spinal cord and it can prevent the destruction of axonal myelin. Also, it can cause a decrease in the size of the central cavity and enhance motor function. ${ }^{70}$ Oron et al proposed the transcranial application of LLL after traumatic brain injury could provide a striking functional neurological benefit and reduces brain tissue damage. ${ }^{71}$ It is well documented that LLL can promote axonal regeneration and functional recovery in rat
SCI. $^{72,73}$ Previous studies ${ }^{36,42,43,63-69}$ (Table 1) have clearly documented that the application of photobiomodulation can have beneficial effects on the treatment of ischemicreperfusion model through decreasing inflammatory factors, inhibiting programmed cell death, stimulating angiogenesis, and enhancing neurogenesis. ${ }^{74}$ In addition, it has been shown that laser therapy can significantly decrease CD68 positive cells in the site of neuronal injury, and the beneficial results of this therapeutic manner in the regulation of immune cell proliferation have been demonstrated, which may have impressed the reduction in neural cell death, having significant effects on the recovery of function behavior. ${ }^{75}$

The results of Rochkind and colleagues' study have shown that the treatment of a transected SCI animal model by a composite implant and laser irradiation $(780 \mathrm{~nm})$ can improve axonal re-growth and spinal cord healing. ${ }^{76}$ On the other hand, experimental studies by Wu et al determined that photobiomodulation $(810 \mathrm{~nm})$ had striking effects on improving axonal restoration and functional recovery in both dorsal hemisection and contusion models of SCI. ${ }^{73}$

It is also proposed that LLL can regulate the inflammatory reactions, modulate the secondary damage, and reduce programmed cell death and edema in the primary phase of recovery.

\section{Conclusion}

According to the results of previous studies, LLL can promote functional recovery in a contusion model of the SCI, which can emphasize LLL application in CNS injury as a favorable non-invasive therapy for clinical usage.

Table 1. Some Studies About the Effect of LLL in SCI

\begin{tabular}{|c|c|c|c|c|}
\hline Author & Year & Title & SCI Model & Length of Radiation \\
\hline Svobodova et $\mathrm{a}^{63}$ & 2019 & $\begin{array}{l}\text { The effect of } 808 \mathrm{~nm} \text { and } 905 \mathrm{~nm} \text { wavelength light on recovery after } \\
\mathrm{SCl}\end{array}$ & Compression & 808 and $905 \mathrm{~nm}$ \\
\hline Kim et $\mathrm{l}^{64}$ & 2017 & $\begin{array}{l}\text { Low-level laser irradiation improves motor recovery after contusive } \\
\mathrm{SCl} \text { in rats }\end{array}$ & Contusion & $850 \mathrm{~nm}$ \\
\hline Janzadeh et al ${ }^{36}$ & 2017 & $\begin{array}{l}\text { Combine effect of Chondroitinase } \mathrm{ABC} \text { and low level laser }(660 \mathrm{~nm}) \\
\text { on } \mathrm{SCl} \text { model in adult male rats }\end{array}$ & Compression & $660 \mathrm{~nm}$ \\
\hline Veronez et al ${ }^{65}$ & 2017 & $\begin{array}{l}\text { Effects of different fluences of low-level laser therapy in an } \\
\text { experimental model of } \mathrm{SCl} \text { in rats }\end{array}$ & Contusion & $808 \mathrm{~nm}$ \\
\hline Song et $\mathrm{al}^{42}$ & 2017 & $\begin{array}{l}\text { Low-level laser facilitates alternatively activated macrophage/ } \\
\text { microglia polarization and promotes functional recovery after crush } \\
\mathrm{SCl} \text { in rats }\end{array}$ & Compression & $810 \mathrm{~nm}$ \\
\hline Hu et al ${ }^{66}$ & 2016 & $\begin{array}{l}\text { Red LED photobiomodulation reduces pain hypersensitivity and } \\
\text { improves sensorimotor function following mild T10 hemicontusion } \\
\mathrm{SCl}\end{array}$ & Hemicontusion & $670 \mathrm{~nm}$ \\
\hline Paula et $\mathrm{l}^{67}$ & 2014 & Low-intensity laser therapy effect on the recovery of traumatic SCl & Contusion & $780 \mathrm{~nm}$ \\
\hline Ando et al ${ }^{43}$ & 2013 & Low-level laser therapy for $\mathrm{SCl}$ in rats: effects of polarization & Contusion & $808 \mathrm{~nm}$ \\
\hline Wu et $\mathrm{al}^{68}$ & 2009 & $\begin{array}{l}810 \mathrm{~nm} \text { Wavelength light: An effective therapy for transected or } \\
\text { contused rat spinal cord }\end{array}$ & $\begin{array}{l}\text { Contusion and } \\
\text { Hemisection }\end{array}$ & $810 \mathrm{~nm}$ \\
\hline Byrnes et $a^{69}$ & 2005 & $\begin{array}{l}\text { Light promotes regeneration and functional recovery and alters the } \\
\text { immune response after } \mathrm{SCl}\end{array}$ & Hemisection & $810 \mathrm{~nm}$ \\
\hline
\end{tabular}




\section{Ethical Considerations}

Not applicable.

\section{Conflict of Interests}

The authors declare no conflict of interest.

\section{References}

1. Lin L, Lin H, Bai S, Zheng L, Zhang X. Bone marrow mesenchymal stem cells (BMSCs) improved functional recovery of SCI partly by promoting axonal regeneration. Neurochem Int. 2018;115:80-4.

2. Choi JS, Leem JW, Lee KH, Kim SS, Suh-Kim H, Jung SJ, Kim UJ, Lee BH. Effects of human mesenchymal stem cell transplantation combined with polymer on functional recovery following spinal cord hemisection in rats. The Korean J Physiol Pharmacol. 2012 1;16(6):405-11.

3. Abbaszadeh HA, Tiraihi T, Delshad AR, Zadeh MS, Taheri T. Bone marrow stromal cell transdifferentiation into oligodendrocyte-like cells using triiodothyronine as a inducer with expression of platelet-derived growth factor $\alpha$ as a maturity marker. Iran Biomed J. 2013;17(2):62.

4. Abrams GM, Ganguly K. Management of chronic spinal cord dysfunction. Continuum (Minneap Minn). 2015;21(1 Spinal Cord Disorders):188-200.

5. Abbaszadeh HA, Niknazar S, Darabi S, Ahmady Roozbahany N, Noori-Zadeh A, Ghoreishi SK, Khoramgah MS, Sadeghi Y. Stem cell transplantation and functional recovery after spinal cord injury: a systematic review and meta-analysis. Anat Cell Biol. 2018;51(3):180-8.

6. Yu C, Xia K, Gong Z, Ying L, Shu J, Zhang F, Chen Q, Li F, Liang C. The application of neural stem/progenitor cells for regenerative therapy of SCI. Curr Stem Cell Res Ther. 2019;14(6):495-503.

7. Massetti J, Stein DM. SCI. In: White JL, Sheth KN, editors. Neurocritical care for the advanced practice clinician. Cham, Switzerland: Springer; 2018. p. 269-88. doi:10.1007/978-3-319-48669-7_15.

8. Fan B, Wei Z, Yao X, Shi G, Cheng X, Zhou X, et al. Microenvironment imbalance of SCI. Cell Transplant. 2018;27(6):853-66. doi: 10.1177/0963689718755778.

9. Ahuja CS, Wilson JR, Nori S, Kotter MR, Druschel C, Curt A, et al. Traumatic SCI. Nat Rev Dis Primers. 2017;3:17018. doi: 10.1038/nrdp.2017.18.

10. Wu Q, Li YL, Ning GZ, Feng SQ, Chu TC, Li Y, et al. Epidemiology of traumatic cervical SCI in Tianjin, China. Spinal Cord. 2012;50(10):740-4. doi: 10.1038/sc.2012.42.

11. Blesch A, Lu P, Tuszynski MH. Neurotrophic factors, gene therapy, and neural stem cells for spinal cord repair. Brain Res Bull. 2002;57(6):833-8. doi: 10.1016/s03619230(01)00774-2.

12. Pineau I, Lacroix S. Proinflammatory cytokine synthesis in the injured mouse spinal cord: multiphasic expression pattern and identification of the cell types involved. $J$ Comp Neurol. 2007;500(2):267-85. doi: 10.1002/cne.21149.

13. PapaS, Mauri E, Rossi F, Perale G, Veglianese P. Introduction to SCI as clinical pathology. In: Perale G, Rossi F, editors. SCI Repair Strategies. Amsterdam: Elsevier; 2019. p. 1-12. doi: 10.1016/B978-0-08-102807-0.00001-6.

14. Chen CH, Sung CS, Huang SY, Feng CW, Hung HC, Yang $\mathrm{SN}$, et al. The role of the PI3K/Akt/mTOR pathway in glial scar formation following SCI. Exp Neurol. 2016;278:27-41. doi: 10.1016/j.expneurol.2016.01.023.

15. Anwar MA, Al Shehabi TS, Eid AH. Inflammogenesis of secondary SCI. Front Cell Neurosci. 2016;10:98. doi: 10.3389/fncel.2016.00098.

16. Mataliotakis GI, Tsirikos AI. Spinal cord trauma: pathophysiology, classification of SCI syndromes, treatment principles and controversies. Orthop Trauma. 2016;30(5):440-9. doi: 10.1016/j.mporth.2016.07.006.

17. Beattie MS, Farooqui AA, Bresnahan JC. Review of current evidence for apoptosis after SCI. J Neurotrauma. 2000;17(10):915-25. doi: 10.1089/neu.2000.17.915.

18. Beattie MS. Inflammation and apoptosis: linked therapeutic targets in SCI. Trends Mol Med. 2004;10(12):580-3. doi: 10.1016/j.molmed.2004.10.006.

19. Rust R, Kaiser J. Insights into the dual role of inflammation after SCI. J Neurosci. 2017;37(18):4658-60. doi: 10.1523/ JNEUROSCI.0498-17.2017.

20. Kwon BK, Tetzlaff W, Grauer JN, Beiner J, Vaccaro AR. Pathophysiology and pharmacologic treatment of acute SCI. Spine J. 2004;4(4):451-64. doi: 10.1016/j. spinee.2003.07.007.

21. Zhou X, He X, Ren Y. Function of microglia and macrophages in secondary damage after SCI. Neural Regen Res. 2014;9(20):1787-95. doi: 10.4103/1673-5374.143423.

22. Dasari VR, Veeravalli KK, Dinh DH. Mesenchymal stem cells in the treatment of spinal cord injuries: A review. World J Stem Cells. 2014;6(2):120-33. doi: 10.4252/wjsc. v6.i2.120.

23. Marques SA, Almeida FM, Fernandes AM, dos Santos Souza C, Cadilhe DV, Rehen SK, et al. Predifferentiated embryonic stem cells promote functional recovery after spinal cord compressive injury. Brain Res. 2010;1349:11528. doi: 10.1016/j.brainres.2010.06.028.

24. Schwab JM, Brechtel K, Mueller CA, Failli V, Kaps HP, Tuli SK, et al. Experimental strategies to promote spinal cord regeneration-an integrative perspective. Prog Neurobiol. 2006;78(2):91-116. doi: 10.1016/j.pneurobio.2005.12.004.

25. Casha S, Yu WR, Fehlings MG. Oligodendroglial apoptosis occurs along degenerating axons and is associated with FAS and p75 expression following SCI in the rat. Neuroscience. 2001;103(1):203-18. doi: 10.1016/s0306-4522(00)00538-8.

26. Chen SW, Xie YF. Glial implications in transplantation therapy of SCI. Chin J Traumatol. 2009;12(1):55-61.

27. Niknazar S, Nahavandi A, Peyvandi AA, Peyvandi H, Roozbahany NA, Abbaszadeh HA. Hippocampal NR3C1 DNA methylation can mediate part of preconception paternal stress effects in rat offspring. Behav Brain Res. 2017 May 1;324:71-76. doi: 10.1016/j.bbr.2017.02.014

28. Gensel JC, Zhang B. Macrophage activation and its role in repair and pathology after SCI. Brain Res. 2015;1619:1-11. doi: 10.1016/j.brainres.2014.12.045.

29. Prüss H, Kopp MA, Brommer B, Gatzemeier N, Laginha I, Dirnagl U, et al. Non-resolving aspects of acute inflammation after SCI: indices and resolution plateau. Brain Pathol. 2011;21(6):652-60. doi: 10.1111/j.17503639.2011.00488.x.

30. Beck KD, Nguyen HX, Galvan MD, Salazar DL, Woodruff TM, Anderson AJ. Quantitative analysis of cellular inflammation after traumatic SCI: evidence for a multiphasic inflammatory response in the acute to chronic 
environment. Brain. 2010;133(Pt2):433-47. doi: 10.1093/ brain/awp322.

31. Takahashi JL, Giuliani F, Power C, Imai Y, Yong VW. Interleukin- $1 \beta$ promotes oligodendrocyte death through glutamate excitotoxicity. Ann Neurol. 2003;53(5):588-95. doi: 10.1002/ana.10519.

32. Darabi S, Tiraihi T, Noori-Zadeh A, Rajaei F, Darabi L, Abbaszadeh HA. Creatine and retinoic acid effects on the induction of autophagy and differentiation of adipose tissue-derived stem cells into GABAergic-like neurons. J Babol Univ Med Sci. 2017;19(8):41-9. doi: 10.22088/ jbums.19.8.41.

33. Plemel JR, Wee Yong V, Stirling DP. Immune modulatory therapies for SCI-past, present and future. Exp Neurol. 2014;258:91-104. doi: 10.1016/j.expneurol.2014.01.025.

34. Shi Z, Huang H, Feng S. Stem cell-based therapies to treat SCI: a review. J Neurorestoratology. 2017;5(1):125-31. doi: $10.2147 / J N . S 139677$.

35. Qu J, Zhang H. Roles of mesenchymal stem cells in SCI. Stem Cells Int. 2017;2017:5251313. doi: 10.1155/2017/5251313.

36. Janzadeh A, Sarveazad A, Yousefifard M, Dameni S, Samani FS, Mokhtarian K, et al. Combine effect of Chondroitinase $\mathrm{ABC}$ and low level laser $(660 \mathrm{~nm})$ on SCI model in adult male rats. Neuropeptides. 2017;65:90-9. doi: 10.1016/j. npep.2017.06.002.

37. Hosseini M, Yousefifard M, Baikpour M, Rahimi-Movaghar V, Nasirinezhad F, Younesian S, et al. The efficacy of Schwann cell transplantation on motor function recovery after spinal cord injuries in animal models: a systematic review and meta-analysis. J Chem Neuroanat. 2016;78:10211. doi: 10.1016/j.jchemneu.2016.09.002.

38. Hosseini M, Karami Z, Janzadenh A, Jameie SB, Haji Mashhadi Z, Yousefifard M, et al. The effect of intrathecal administration of muscimol on modulation of neuropathic pain symptoms resulting from SCI; an experimental study. Emerg (Tehran). 2014;2(4):151-7.

39. Mojarad N, Yousefifard M, Janzadeh A, Damani S, Golab F, Nasirinezhad F. Comparison of the antinociceptive effect of intrathecal versus intraperitoneal injection of paracetamol in neuropathic pain condition. J Med Physiol. 2016;1(1):106.

40. Ruppert KA, Nguyen TT, Prabhakara KS, Toledano Furman NE, Srivastava AK, Harting MT, et al. Human mesenchymal stromal cell-derived extracellular vesicles modify microglial response and improve clinical outcomes in experimental SCI. Sci Rep. 2018;8(1):480. doi: 10.1038/ s41598-017-18867-w.

41. Kobiela Ketz A, Byrnes KR, Grunberg NE, Kasper CE, Osborne L, Pryor B, et al. Characterization of macrophage/ microglial activation and effect of photobiomodulation in the spared nerve injury model of neuropathic pain. Pain Medicine. 2017 May 1;18(5):932-46.

42. Song JW, Li K, Liang ZW, Dai C, Shen XF, Gong YZ, et al. Low-level laser facilitates alternatively activated macrophage/microglia polarization and promotes functional recovery after crush SCI in rats. Sci Rep. 2017;7(1):620. doi: 10.1038/s41598-017-00553-6.

43. Ando T, Sato S, Kobayashi H, Nawashiro H, Ashida H, Hamblin MR, et al. Low-level laser therapy for SCI in rats: effects of polarization. J Biomed Opt. 2013;18(9):098002. doi: 10.1117/1.JBO.18.9.098002.
44. Anders JJ. The potential of light therapy for central nervous system injury and disease. Photomed Laser Surg. 2009;27(3):379-80. doi: 10.1089/pho.2009.0053.

45. Mohsenifar Z, Fridoni M, Ghatrehsamani M, Abdollahifar MA, Abbaszadeh H, Mostafavinia A, et al. Evaluation of the effects of pulsed wave LLL on tibial diaphysis in two rat models of experimental osteoporosis, as examined by stereological and real-time PCR gene expression analyses. Lasers Med Sci. 2016;31(4):721-32.

46. Ekim A, Armagan O, Tascioglu F, Oner C, Colak M . Effect of low level laser therapy in rheumatoid arthritis patients with carpal tunnel syndrome. Swiss Med Wkly. 2007; 137(23-24):347-52.

47. de Carvalho Pde T, Leal-Junior EC, Alves AC, Rambo CS, Sampaio LM, Oliveira CS, et al. Effect of low-level laser therapy on pain, quality of life and sleep in patients with fibromyalgia: study protocol for a double-blinded randomized controlled trial. Trials. 2012;13(1):221. doi: 10.1186/1745-6215-13-221.

48. Shirani AM, Gutknecht N, Taghizadeh M, Mir M. Low-level laser therapy and myofacial pain dysfunction syndrome: a randomized controlled clinical trial. Lasers Med Sci. 2009;24(5):715-20. doi: 10.1007/s10103-008-0624-5.

49. Masoumipoor M, Jameie SB, Janzadeh A, Nasirinezhad F, Soleimani M, Kerdary M. Effects of 660-and 980-nm lowlevel laser therapy on neuropathic pain relief following chronic constriction injury in rat sciatic nerve. Lasers Med Sci. 2014;29(5):1593-8. doi: 10.1007/s10103-014-1552-1.

50. Rochkind S, Rousso M, Nissan M, Villarreal M, Barr-Nea L, Rees DG. Systemic effects of low-power laser irradiation on the peripheral and central nervous system, cutaneous wounds, and burns. Lasers Surg Med. 1989;9(2):174-82. doi: 10.1002/lsm.1900090214.

51. Aimbire F, Albertini R, Pacheco MT, Castro-Faria-Neto HC, Leonardo PS, Iversen VV, et al. Low-level laser therapy induces dose-dependent reduction of TNFa levels in acute inflammation. Photomed Laser Surg. 2006;24(1):33-7. doi: 10.1089/pho.2006.24.33.

52. Aimbire F, Ligeiro de Oliveira AP, Albertini R, Corrêa JC, Ladeira de Campos CB, Lyon JP, et al. Low level laser therapy (LLL) decreases pulmonary microvascular leakage, neutrophil influx and IL-1 $\beta$ levels in airway and lung from rat subjected to LPS-induced inflammation. Inflammation. 2008;31(3):189-97. doi: 10.1007/s10753-008-9064-4.

53. Huang YY, Gupta A, Vecchio D, de Arce VJ, Huang SF, Xuan W, et al. Transcranial low level laser (light) therapy for traumatic brain injury. J Biophotonics. 2012;5(11-12):82737. doi: 10.1002/jbio.201200077.

54. Chung H, Dai T, Sharma SK, Huang YY, Carroll JD, Hamblin MR. The nuts and bolts of low-level laser (light) therapy. Ann Biomed Eng. 2012;40(2):516-33. doi: 10.1007/ s10439-011-0454-7.

55. Chen YJ, Wang YH, Wang CZ, Ho ML, Kuo PL, Huang $\mathrm{MH}$, et al. Effect of low level laser therapy on chronic compression of the dorsal root ganglion. PloS One. 2014;9(3):e89894. doi: 10.1371/journal.pone.0089894.

56. Detaboada L, Ilic S, Leichliter-Martha S, Oron U, Oron A, Streeter J. Transcranial application of low-energy laser irradiation improves neurological deficits in rats following acute stroke. Lasers Surg Med. 2006;38(1):70-3. doi: 10.1002/lsm.20256. 
57. Mester E, Mester AF, Mester A. The biomedical effects of laser application. Lasers Surg Med. 1985;5(1):31-9. doi: 10.1002/lsm.1900050105.

58. Ojaghi R, Sohanaki H, Ghasemi T, Keshavarz F, Yousefifard M, Sadeghipour HR. Role of low-intensity laser therapy on naloxone-precipitated morphine withdrawal signs in mice: is nitric oxide a possible candidate mediator? Lasers Med Sci. 2014;29(5):1655-9. doi: 10.1007/s10103-014-1530-7.

59. Campana VR, Moya M, Gavotto A, Soriano F, Juri HO, Spitale LS, et al. The relative effects of He-Ne laser and meloxicam on experimentally induced inflammation. Laser Ther. 1999;11(1):36-42. doi: 10.5978/islsm.11.36.

60. Albertini R, Aimbire FS, Correa FI, Ribeiro W, Cogo JC, Antunes E, et al. Effects of different protocol doses of low power gallium-aluminum-arsenate ( $\mathrm{Ga}-\mathrm{Al}-\mathrm{As})$ laser radiation $(650 \mathrm{~nm})$ on carrageenan induced rat paw ooedema. J Photochem Photobiol B. 2004;74(2-3):101-7. doi: 10.1016/j.jphotobiol.2004.03.002.

61. Rizzi CF, Mauriz JL, Freitas Corrêa DS, Moreira AJ, Zettler CG, Filippin LI, et al. Effects of low-level laser therapy (LLL) on the nuclear factor (NF)- $\kappa B$ signaling pathway in traumatized muscle. Lasers Surg Med. 2006;38(7):704-13. doi: 10.1002/lsm.20371.

62. Albertini R, Villaverde AB, Aimbire F, Salgado MA, Bjordal JM, Alves LP, et al. Anti-inflammatory effects of low-level laser therapy (LLL) with two different red wavelengths (660 $\mathrm{nm}$ and $684 \mathrm{~nm}$ ) in carrageenan-induced rat paw edema. J Photochem Photobiol B. 2007;89(1):50-5. doi: 10.1016/j. jphotobiol.2007.08.005.

63. Svobodova B, Kloudova A, Ruzicka J, Kajtmanova L, Navratil L, Sedlacek R, et al. The effect of $808 \mathrm{~nm}$ and 905 $\mathrm{nm}$ wavelength light on recovery after spinal cord injury. Sci Rep. 2019;9(1):1-14. doi: 10.1038/s41598-019-44141-2

64. Kim J, Kim E-H, Lee K, Kim B, Kim Y, Na SH, et al. Lowlevel laser irradiation improves motor recovery after contusive spinal cord injury in rats. J Tissue Eng Regen Med. 2017;14(1):57-64. doi: 10.1007/s13770-016-0003-4

65. Veronez S, Assis L, Del Campo P, de Oliveira F, de Castro G, Renno ACM, et al. Effects of different fluences of lowlevel laser therapy in an experimental model of SCI in rats. Lasers Med Sci. 2017;32(2):343-9. doi: 10.1007/s10103016-2120-7.

66. $\mathrm{Hu} \mathrm{D}$, Zhu S, Potas JR. Red LED photobiomodulation reduces pain hypersensitivity and improves sensorimotor function following mild T10 hemicontusion SCI. J Neuroinflammation. 2016;13(1):200. doi: 10.1186/s12974016-0679-3

67. Paula AA, Nicolau RA, Lima MdO, Salgado MAC, Cogo JC. "Low-intensity laser therapy effect on the recovery of traumatic spinal cord injury". Lasers Med Sci. 2014;29(6):1849-59. doi: 10.1007/s10103-014-1586-4

68. Wu X, Dmitriev AE, Cardoso MJ, Viers-Costello AG, Borke $\mathrm{RC}$, Streeter J, et al. $810 \mathrm{~nm}$ wavelength light: an effective therapy for transected or contused rat spinal cord. Lasers Surg Med. 2009;41(1):36-41. doi: 10.1002/lsm.20729.

69. Byrnes KR, Waynant RW, Ilev IK, Wu X, Barna L, Smith K, et al. Light promotes regeneration and functional recovery and alters the immune response after SCI. Lasers Surg Med. 2005;36(3):171-85. doi: 10.1002/lsm.20143.

70. Gupta A, Keshri GK, Yadav A, Gola S, Chauhan S, Salhan AK, et al. Superpulsed (Ga-As, $904 \mathrm{~nm}$ ) low-level laser therapy (LLL) attenuates inflammatory response and enhances healing of burn wounds. J Biophotonics. 2015;8(6):489-501. doi: 10.1002/jbio.201400058.

71. Hamblin MR. Mechanisms and applications of the antiinflammatory effects of photobiomodulation. AIMS biophys. 2017;4(3):337-61. doi: 10.3934/biophy.2017.3.337.

72. Lapchak PA, Wei J, Zivin JA. Transcranial infrared laser therapy improves clinical rating scores after embolic strokes in rabbits. Stroke. 2004;35(8):1985-8. doi: 10.1161/01. STR.0000131808.69640.b7.

73. Oron A, Oron U, Chen J, Eilam A, Zhang C, Sadeh M, et al. Low-level laser therapy applied transcranially to rats after induction of stroke significantly reduces long-term neurological deficits. Stroke. 2006;37(10):2620-4. doi: 10.1161/01.STR.0000242775.14642.b8

74. Naveh N, Bar-Ilan A, Rosner M, Schwartz M, Weissman C, Belkin M. Low-energy laser irradiation-a new measure for suppression of arachidonic acid metabolism in the optic nerve. J Neurosci Res. 1990;26(3):386-9. doi: 10.1002/ jnr.490260316.

75. Rochkind S, Barrnea L, Razon N, Bartal A, Schwartz M. Stimulatory effect of He-Ne low dose laser on injured sciatic nerves of rats. Neurosurgery. 1987;20(6):843-7. doi: 10.1227/00006123-198706000-00004.

76. Gonçalves ED, Souza PS, Lieberknecht V, Fidelis GS, Barbosa RI, Silveira PC, et al. Low-level laser therapy ameliorates disease progression in a mouse model of multiple sclerosis. Autoimmunity. 2016;49(2):132-42. doi: 10.3109/08916934.2015.1124425.

77. Oron A, Oron U, Streeter J, de Taboada L, Alexandrovich A, Trembovler V, et al. Low-level laser therapy applied transcranially to mice following traumatic brain injury significantly reduces long-term neurological deficits. J Neurotrauma. 2007;24(4):651-6. doi: 10.1089/ neu.2006.0198

78. Sotoudeh A, Jahanshahi A, Zareiy S, Darvishi M, Roodbari $\mathrm{N}$, Bazzazan A. The influence of low-level laser irradiation on spinal cord injuries following ischemia-reperfusion in rats. Acta Cir Bras. 2015;30(9):611-6.

79. Rochkind S, Shahar A, Alon M, Nevo Z. Transplantation of embryonal spinal cord nerve cells cultured on biodegradable microcarriers followed by low power laser irradiation for the treatment of traumatic paraplegia in rats. Neurol Res. 2002;24(4):355-60. 